\title{
The effects of Petroselinum crispum extract on milk production parameters in female rats
}

\section{Roshankhah $\mathbf{S}^{1}$, Jalili $\mathbf{C}^{2}$, Salahshoor $\mathbf{M R}^{3}$}

1. Assistant Professor of Anatomical Sciences, Department of Anatomy, Faculty of Medicine, Kermanshah University of Medical Sciences, Kermanshah, Iran.

2. Professor of Anatomical Science, Medical Biology Research Center, Kermanshah University of Medical Sciences, Kermanshah, Iran.

3. Associated Professor, Department of Anatomy, Faculty of Medicine, Kermanshah University of Medical Sciences, Kermanshah, Iran, (Corresponding Author) Tel: +98-831-7256181, Email: reza.salahshoor@yahoo.com

\begin{abstract}
Background and Aim: Use of medicinal plants is one of the methods to increase breast milk. Petroselinum crispum is a multipurpose herb in traditional medicine which contains essential amino acids, vitamins and numerous nutrients. This study aimed to determine the effects of Petroselinum crispum extract on milk production parameters in female rats.

Material and Methods: In this experimental study, 32 Wistar female rats were randomly assigned to 4 groups; group1, control group (normal saline) and groups 2 to 4 (experimental groups). The experimental groups received various doses of Petroselinum crispum $(100,150$, $200 \mathrm{mg} / \mathrm{kg} /$ day intraperitoneally) for 21 days. Petroselinum crispum extract was prepared. Prolactin hormone measurements were carried out based on RIA prolactin radio immune assay method. Using morphometrical techniques, prolactin receptor (PRLR) mRNA expression level and histological evaluation of mammary gland tissue were investigated. Data were analyzed by one way ANOVA test.

Results: Petroselinum crispum administration increased significantly all the parameters in experimental groups compared to those in the control group $(\mathrm{P}<0.0001)$.

Conclusion: Petroselinum crispum extract had positive effects on the milk production parameters in mammary glands.
\end{abstract}

Keywords: Petroselinum crispum, Milk production, Rat

Recevied: Dec 9, 2018

Accepted: Feb 20. 2019

How to cite the article: Roshankhah S, Jalili C, Salahshoor MR. The effects of Petroselinum crispum extract on milk production parameters in female rats. SJKU 2019; 24 (1): 11-23.

Copyright (C) 2019 the Author (s). Published by Kurdistan University of Medical Sciences. This is an open access article distributed under the terms of the Creative Commons Attribution-Non Commercial License 4.0 (CCBY$\mathrm{NC}$ ), where it is permissible to download, share, remix, transform, and buildup the work provided it is properly cited. The work cannot be used commercially without permission from the journal. 


\section{اثرات عصاره كياه يتروسيلينوم كريسيوم بريار امتر هاى توليد شير در موشهاى صحرايى ماده}

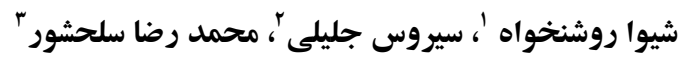

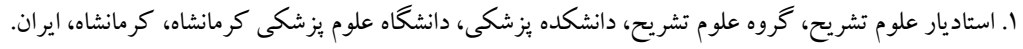

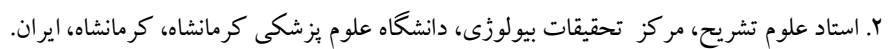

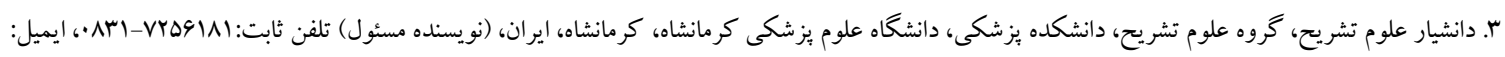

زمينه و هدف: استفاده از گياهان دارويى يكى از روشهاى افزايش توليد شير در بستان بوده است. بتروسيلينوم كريسيوم گياهى

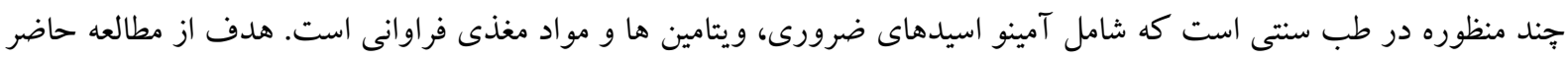

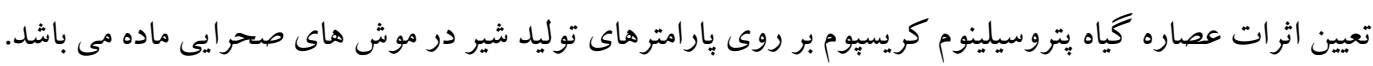

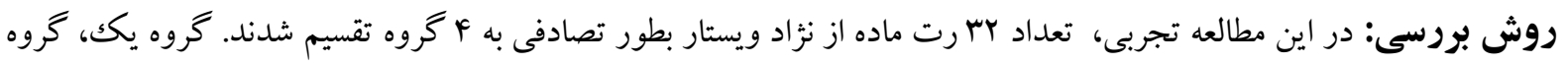

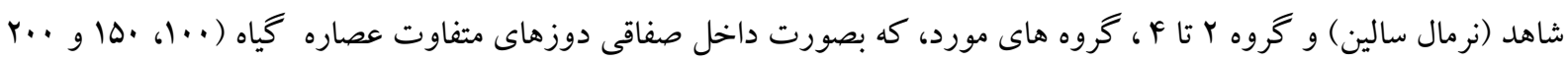

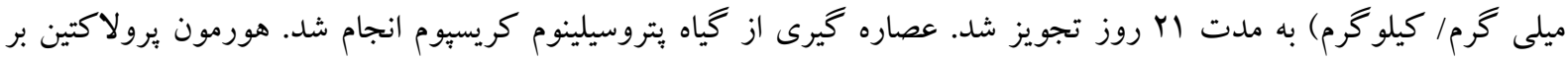

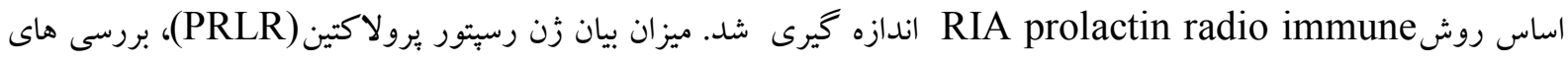

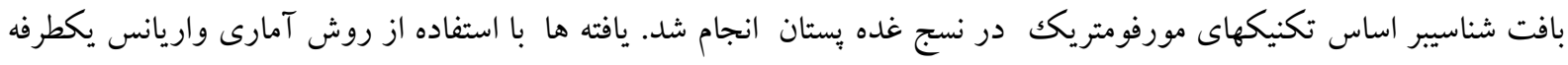

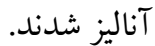
يافته ها: تجويز يتروسيلينوم كريسبوم در تمام گروه هاى مورد مطالعه، موجب افزايش معنى دارى در تمام بارامترهاى مورد

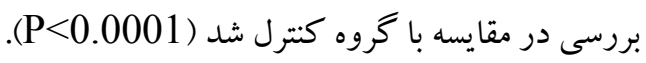
نتيجه كيرى: عصاره يتروسيلينوم كريسيوم اثرات مثبت بر بارامترهاى توليد شير در غدد بِ بستانى دارد.

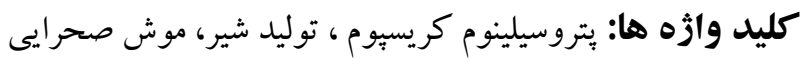

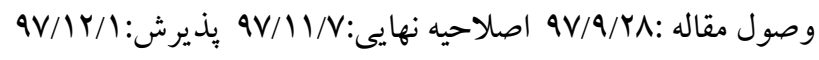




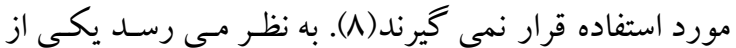
راه هاى افزايش شير مادر استفاده از داروهاى گياهى باشد. كياه جعفرى با نام علمى خانواده جتريان است كه در نزديكى مزارع رشد ميكند و بـه عنوان يكك سبزى دراكثر مناطق ايران مصرف مسى شود (9). بتروسيلينوم كريسيوم خصوصيات تغذيسه و فارمـاكولوزيكى بسيارى دارد. خـو اص متعـددى در خصـوص گيـاه جعفـىى كزارش شده است از جمله بهبود فيبروز كبـدى( • (1)، ادرار آور( (1)، ضد ميكروب(r)(1)، ضد منوروزيا و آنتى اكسيدان قوى(r). همجنين خو اص ديخر يتروسيلينوم كريسيوم شامل تنظيم فشار خون، بهبود اگزما واز بين برنده سنگهاى كليوى مى باشد(f) (I). در طب سنتى از اين گياه بـراى افزايش شسير

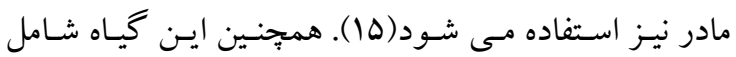
ويتامين C، فيتواسترول، يـروتئين و مـواد نشاسته اى بـوده و

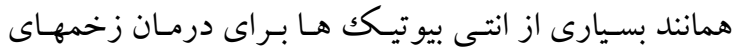
بوسـتى اسـتفاده ميشـود(19). نتــايج حاصـل از آتـاليز نشـان داد كـه تركيبـات آنتسى اكسـيدانى و آنتى HPLC ميكروبى گياه بتروسيلينوم كريسبوم حساوى بيشـترين غلظـت ازعصـاره fumaric acid و بـ ترتيـب بــ carvacrol ميزان هاى مختلف كياه فعاليت آنتى اكسيدانى و خاصسيت خنثى كنندگى راديكالهاى آزاد را نشان داده اند(11). نتـايج مطالعـه AL-Shemary و همكـاران نشـان داد كــ عصاره Ocimum gratissmum به دليل وجود تانن مى تواند موجب افزايش ميزان برولاكتين و متعاقبا افزايش ميزان شـير دهى شـود(1) (1). نتـايج مطالعسه BolzÁn و همكـاران

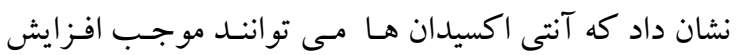

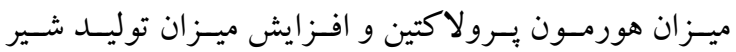
شوند(19). همجنين نتايج مطالعه Gass و همكاران نشان داد كه تر كيبات انتى اكسيدانى مى توانند باعث افزايش بيـان زن PRLR
مراقبت از فرزندان بِ از تولـد و تغذيـه آنـان از مسـائلى است كه اهميت آن بر هيج كسى بوشـيده نيست در ايسن ميان تغذيه انحصارى با شير مادر به عنوان بهترين تغذيه براى كودك تا سن 4 ماهكَى است كه عـلاوه بـر تـامين نيازهـاى

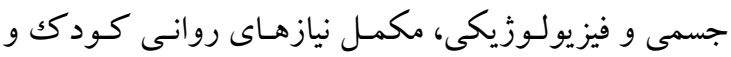
مادر مى باشد( (1). شـير مـادر مسى توانـد سـبب بيشـيرى از برخى بيمارى ها در يكك سال اول زندگى شود (Y). با وجود علاقه مندى و اقدام بيشـتر مـادران بـهـ شـيردهى از يسـتان، كمتر از ·ه درصد مادران قادر بـه ادامسه شـيردهى در طـول مدت مورد نيـاز بـراى شـيرخوار هسـتند و در بيشـتر مـوارد مادران با قطع زودرس شيردهى مواجه مى شوند (r).

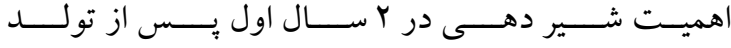
نـــوزادان و مشكلاتى كه در اين زمينه براى مـادران بيش مى ايسـد لــزوم تحقيقات جديد را در جهت دست يابى و توليد داروهاى شير افز ا نشان مى دهد (F). اين در حالى اسـت كـه طبق گزارش سازمان بهداشت جهانى سـالانه ه/ ا ميليون

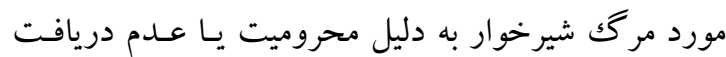
كافى شير مادر اتفاق مى افتد(ه). ميزان ترشح برولاكتين به طور فيزيولوزيك در طى باردارى و يسس از زايمـان در دوران شـيردهى افـزايش مسى يابـــ بـهـ طورى كه در دوران باردارى غلظت يـرولاكتين تـا ·r برابـر بيشتر از حالت عادى است(9). نقش هاى متفاوت برولاكتين همجِون بِايدارى فعاليت ترشحى غدد بِستانى، همر اهى عمل آن با آندروزن ها واثر آن بر متابوليسم آندروزن ها تابه حال

شناخته شده است(V) ( ) - (V).

جهت بهبود شيردهى و افزايش شير مادران راه هاى درمانى مورد نياز است كه برطرف كردن اين نقيصه اغلب از طريق داروهاى شيميايى صورت مى گيـرد. تحقيقـاتى در مـورد داروهاى شيميايى به عنـوان داروهـاى افزاينـده شـير مـادر انجام شده ولى اين داروها به دليل عوارض جانبى، آنجنان 
حمام آب گرم (4 درجه سانتى گراد) و در شرايط تاريكى قرار داده شد. در ادامه محلول از فيلتر كاغذى و يمٍٍ خـلاء عبور داده شد. جهت بدست آوردن محلول اضافى، محلول

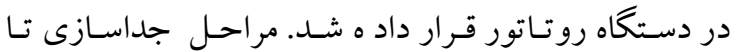
بدست آمدن عصاره ادامه يافت. عصاره در آب مقطر جهت بدست آوردن غلظت هـاى (دوز) مـورد مطالعه رقيـق شـد.

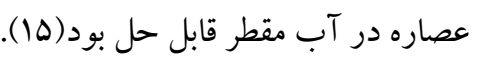
كروه بندى و طراحى مطالعـه: موشهاى صـر ايى بـــ

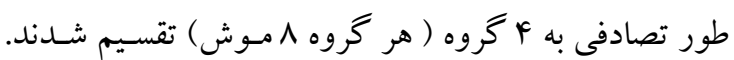

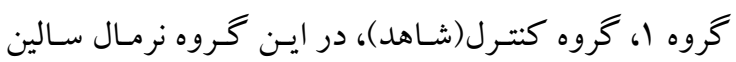
برابر ميزان عصاره تجويز شده در ساير گروه ها دريافت شد.

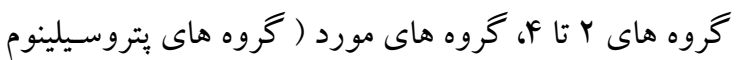

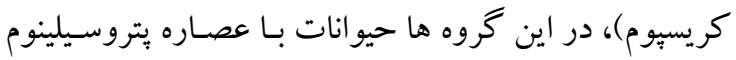

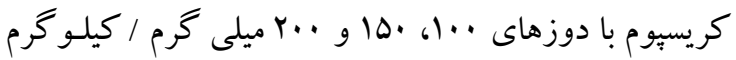

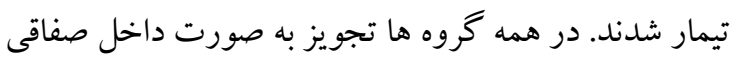

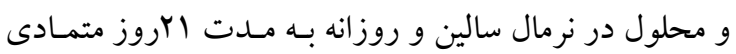

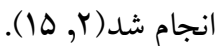

\section{روش راديوايمونو (RIA): جند ساعت ڤֶ از انجام}

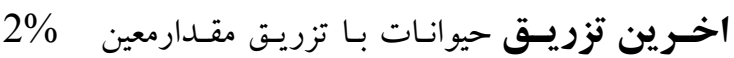
Xy l az ine به وسيله سرنگك، خون گيرى به عمل آمد .خون حيوانـات

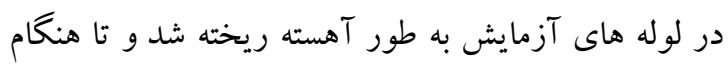

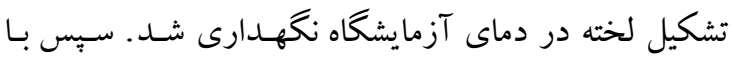

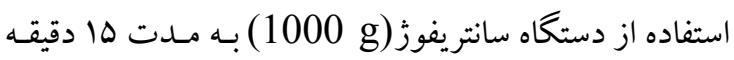

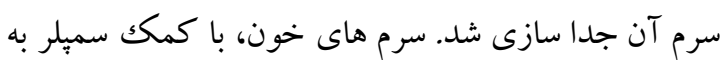

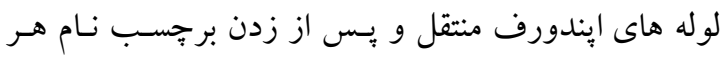

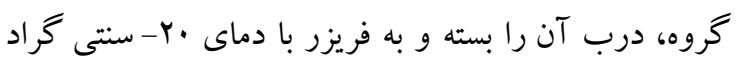

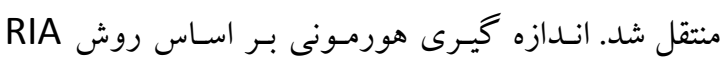

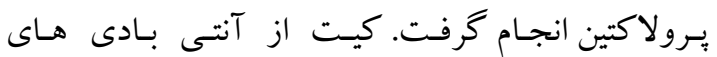

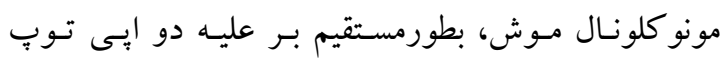

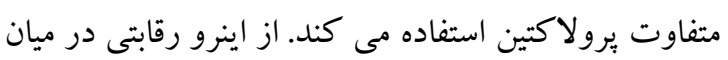

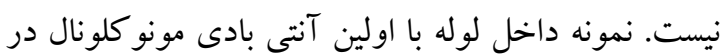

مطالعات فوق مويد اين نكته است كـه كياهـانى بـا خاصيت آنتى اكسيدانى هر يكك به نحوى موجب افزايش ميزان توليد شير يا هورمونهاى توليد كننده شير شده اند. بنابراين با توجه به خواص آنتى اكسيدانى اين گيـاه و وجـود برخى عناصر

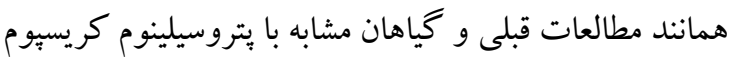
در آن و اينكه تا كنون مطالعه اى بـر روى اثرات عصساره يتروسيلينوم كريسيوم بر غدد هـتانى و ميزان توليـد شـير بـهـ

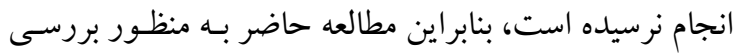

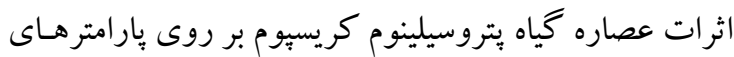
توليد شير در موش هاى صحر ايى ماده به انجام رسيد.

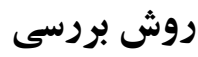
حيوانات آزمايشغاهى: در اين مطالعه تجربى، بـ مـوش

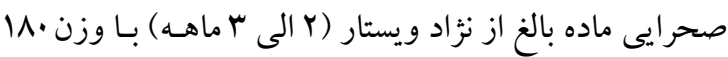

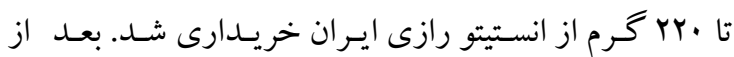
بارورى موشهاى ماده توسط موشههاى نـر و يـس از سيرى شدن ·r روز از باردارى، بـه طـور متوسط هـر مـوش مـادر

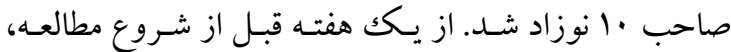

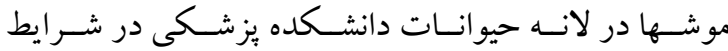

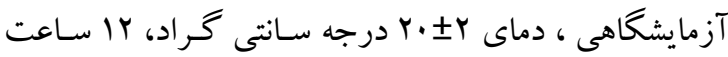

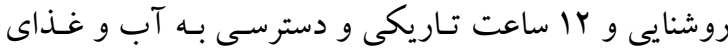
آزاد نخهدارى شدند. هر ^حيوان در يـك قفـس استاندارد قرار داده شد. تمام مراحل مطالعه بر اساس بيانيـه هلسينكىى، قوانين تحقيقـاتى كـار بـا حيوانـات و مصـوبه كميتـه اخـلاق معاونتـت يُزوهشى دانشـاه علـوم يز شـكى كرمانشـاه انجـام

شد(كد اخلاق:IR.KUMS.REC.1397.495 )

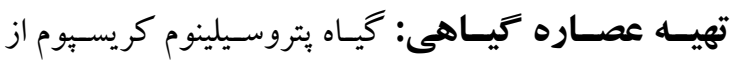

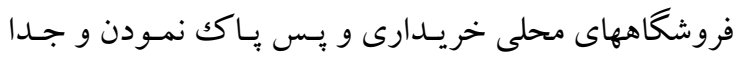
كردن بر گها و ساقه به تاييد گياه شناس رسيد. بر گها و سـاقه

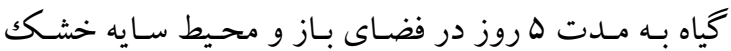

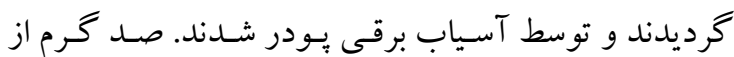

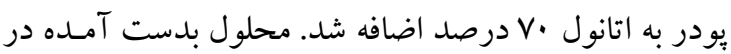


mini kit (Qiagen co)

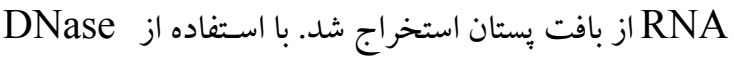

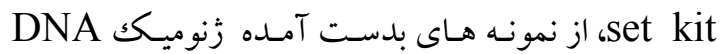
حذف شد. با استفاده از RevertAidTM First Strand RNA ورزن cDNA Synthesis Kit استخراج شده بدست آمد. ميزان بيان زن مورد نظر با استفاده

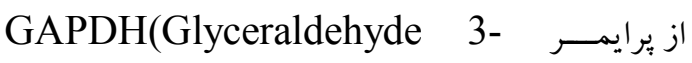

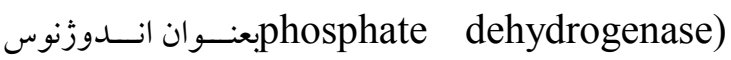
كنترل و بوسيله روش Maxima SYBR Green/Rox qPCR master mix (Fermentas co) تكنيـك (Ct) $\Delta \Delta$ Comparative Ct مشـخص شـد.

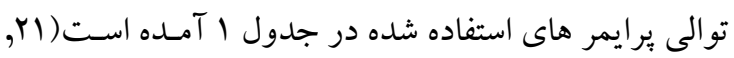

حضور آنتى بـادى مونو كلونـال ثانويـه يوشيده شـــ مـايع موجود در لوله ها بعد از اينكوبه شدن شستشو داده شـدند

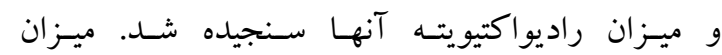

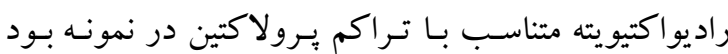

تكنيـك real-time PCR بـراى بدست آوردن ميزان

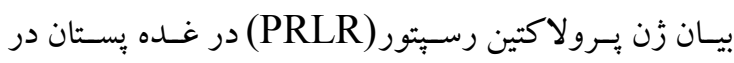
كروه هاى مورد مطالعه، روش Real Time-PCR بكـار

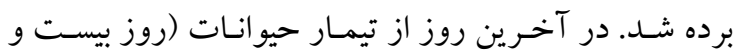
يكم)، حيوانات توسط كلروفورم بيهـوش، كشتهـ و تشريح شدند. غدد بستانى موشها بلافاصله خارج و در نيتروزن مـايع

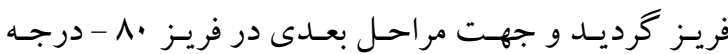

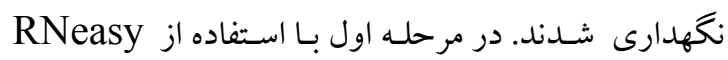

\begin{tabular}{|c|c|}
\hline نام يرايمر & توالى يرايمر ها \\
\hline $\begin{array}{l}\text { GAPDH- } \\
\text { F }\end{array}$ & AAGCTCATTTCCTGGTATG \\
\hline $\begin{array}{l}\text { GAPDH- } \\
\text { R }\end{array}$ & $\begin{array}{c}\text { CTGCCACAAGAACTAGAGGATAA } \\
\text { GA }\end{array}$ \\
\hline PRLR -F & $\begin{array}{c}\text { TCCTATTTGAGTCTGCAGCTTCAGT } \\
\text { AGTCA }\end{array}$ \\
\hline PRLR -R & $\begin{array}{c}\text { CTTCCGTGACCAGAGTCACTGTCGG } \\
\text { GATCT }\end{array}$ \\
\hline
\end{tabular}

GAPDH: Glyceraldehyde3-phosphatedehydrogenase, as endogenous Control. PRLR: prolactin receptor gene

و نمونه ها با استفاده از روش هماتو كسيفيلين و ائوزين رنگك آميزى شدند. بيست برش عرضى از هر بلو كك بـافتى آمـاده

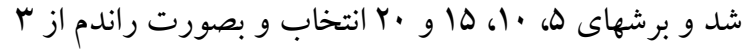

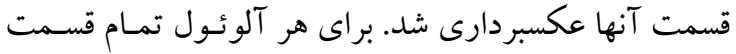

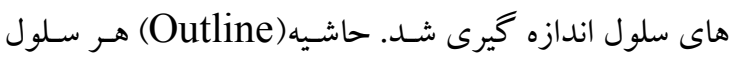
آلوئول توسط ميكروسكوٍٍ نورى با بزرگك نمايى ·F اندازه كيرى شد. بزر گترين و كوخكترين محور هر آلوئول اندازه
بررسى بافت شناسى و مورفو متريك: الف. اندازه كيرى ميانكين قطر آلوئسول هـا. غـد مئد

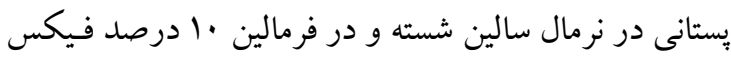

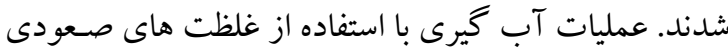
الكل انجام شد. نمونه ها توسط زايلين شفاف سـازى شـده و

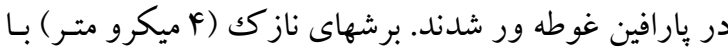

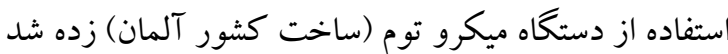


آناليز آمـارى. بـس از كسب اطمينـان از طبيعى بـودن

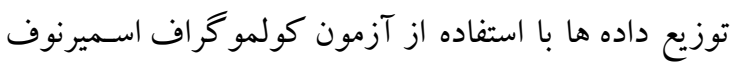

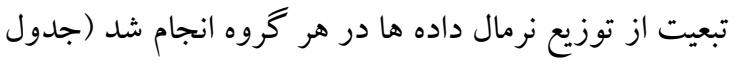

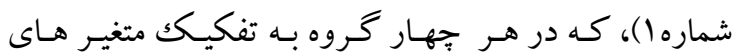

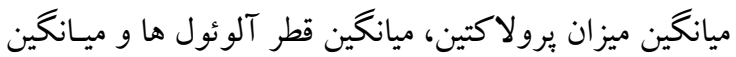

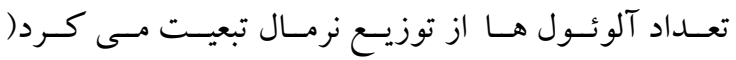

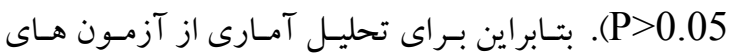
يار امتريك استفاده شد كه با توجه به تعداد گروه ها و برقرار

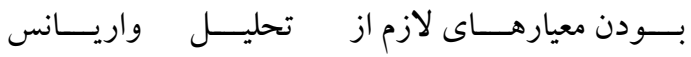

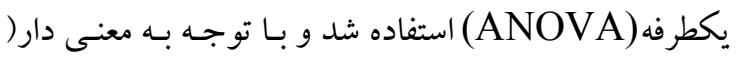
بودن اختلاف ميانگين در هر سه متغيير در بين

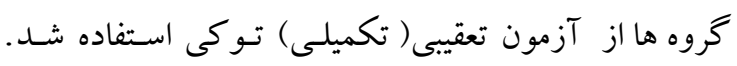

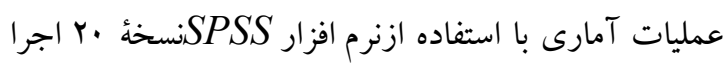

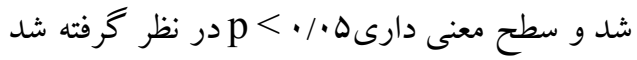

كيرى شد و بر اين اساس ميـانگين مـورد نظر بدست آمـد. حداقل •ها آلوئول از هر ناحيه انـدازه گيـرى شـد. قطر هـر آلوئول از طريق دوربين و نرم افزار موتيكك Moticam) 2000, Spain) ب. تعداد آلوئول ها. بررسى مورفومتريك بوسيله قرار

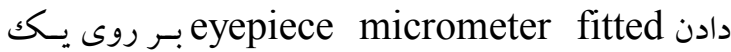
ميكروسكوٍ نورى و با استفاده از بزر گنمايى ·F بـر روى نمونه هاى رنغك آميزى شده توسط روش هماتو كسييلين و

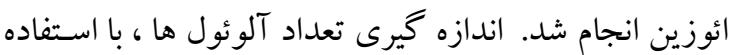
از نمونه هاى غدد بِتانى، ها برش، س فيلد و براى هر اسلايد

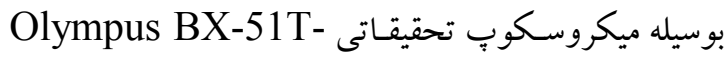

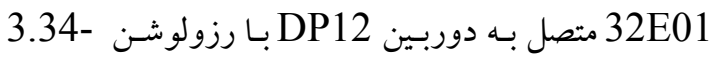

Olysia Bio-software و و نـرم افزار million pixel (Ylympus Optical, Tokyo, Japan)

جدول ا: وضعيت تبعيت از توزيع نرمال متغير هاى فاصله اى مورد مطالعه به تفكيك گروههاى يثزوهش

\begin{tabular}{|c|c|c|c|c|c|c|}
\hline \multicolumn{2}{|c|}{ تعداد آلوئول ها } & \multicolumn{2}{|c|}{ قطر آلوئول ها } & \multicolumn{2}{|c|}{ يرولاكتين } & \multirow{2}{*}{ كروهها } \\
\hline$P_{\text {value }}$ & 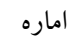 & $\mathrm{P}_{\text {value }}$ & اماره اره & $\mathrm{P}_{\text {value }}$ & اماره اره & \\
\hline$\cdot 1099$ & $\cdot / V \wedge \Delta$ & - /VFF & $\cdot / 91$ & $\cdot / 9 \vee 9$ & $\cdot / F \vee \Lambda$ & Fروه ا (دوز .1) \\
\hline$\cdot / \Lambda \Lambda$ & 1011 & $\cdot / F V \Delta$ & - MAT & $\cdot / 919$ & . AFY & كروه ז ( دوز •dه) \\
\hline$\cdot / Y I I$ & $1 / .91$ &.$/ 449$ & - IAST & $\cdot / 991$ & - MKG & 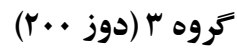 \\
\hline - Irs & $\cdot / 9 \Delta r$ & $\cdot / 499$ & •/А९9 & - /var & $.194 \mathrm{~V}$ & تروه كنترل \\
\hline
\end{tabular}

يافته ها

نتايج توصيفى و تحليلى متغير هاى مطالعه در جهار كروه به تكيك در جدول شماره Y آورده شده است.

جدول r: ميانگين متغيرهاى مورد مطالعه در نمونه هاى يثوهش

\begin{tabular}{|c|c|c|c|c|c|c|}
\hline \multicolumn{2}{|c|}{ تعداد آلوئول ها } & \multicolumn{2}{|c|}{ قطر آلوئول ها } & \multicolumn{2}{|c|}{ يرولاكتين } & \multirow{2}{*}{ كتروهها } \\
\hline انحر اف معيار & ميانگين & انحر اف معيار & ميانگين & انحراف & ميانگين & \\
\hline $1 . r$ & 19 & $4 / 91$ & $1 \cdot V / 91$ & $1 / T F$ & IV/AT & كروه ا (دوز · +1) \\
\hline $1 / \wedge \Delta$ & r. & $9 / 0$ & $110 / \cdot 1$ & $r / l$ & $r \cdot / \Delta r$ & كروه r ( دوز • 10) \\
\hline$\cdot / \Delta F$ & ri & $\Delta / Q F$ & $\mid 1 N / \cdot+1$ & $1 / \cdot 1$ & $r \cdot / \kappa r$ & كروه r (دوز ...r) \\
\hline$\cdot / V^{\prime}$ & 1. & $r / r q$ & $\Lambda \cdot / \Lambda r$ & .194 & $\mid F / T$ & كروه كنترل \\
\hline $\mathrm{F}=1 r r / \wedge q$ & $\mathrm{P}=\cdot / \cdots \cdot 1$ & $F=\Lambda r / \Lambda \mid F$ & $\mathrm{P}=\cdot / \cdots+1$ & $F=r V / r 19$ & $\mathrm{P}=\cdot / \cdots \cdot 1$ & نتايج آمارى \\
\hline
\end{tabular}




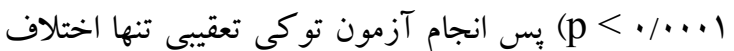
ميانگين غلظت برولاكتين در گروه Y و r با هم تفاوت آمارى معنادار نداشت ولى در ساير حالات تفاوت آمارى

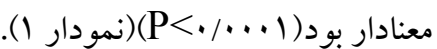

مطالعه هورمونى. ميانگين ميزان هورمون برولاكتين خون به طور معنى دارى در حيوانات تيمار شده با عصاره يتروسيلينوم كريسوِ در تمام دوزهاى مورد بررسى در مقايسه با كروه كنترول به طور معنى دارى بيشتر بود.)

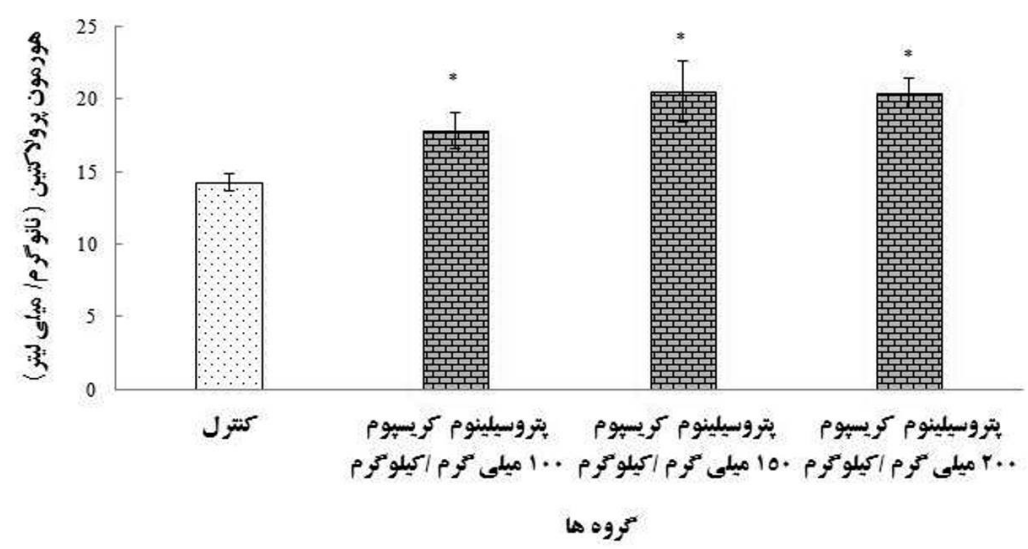

نمودار ا- اثرات بتروسيلينوم كريسيوم بر روى ميزان هورمون يرولاكتين خون در موشهاى صحرايى. إفزايش معنى در در تمامى گروه هاى بتروسيلينوم

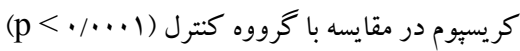
Real-time PCR از تكنيكs real-time PCR نشان داد كه تيمار با عصاره يتروسيلينوم كريسيوم در تمام دوزهاى مورد مطالعه موجب افزايش

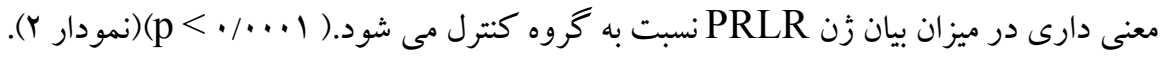

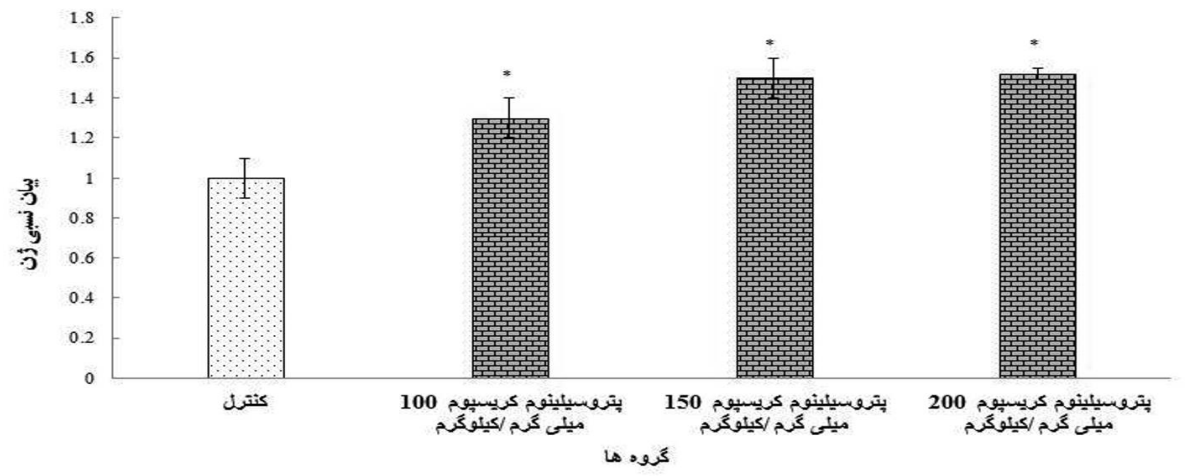

نمودار r- نتايج آرمون Real-time quantitative PCR بر روى ميزان بيان PRLR mRNA در بافت بِتان رت هاى تيمار شده با بتروسيلينوم

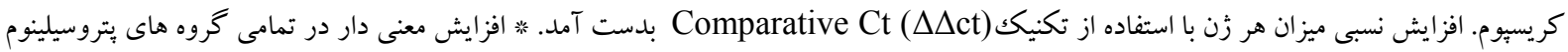

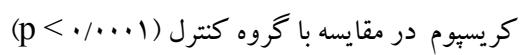

دارى در ميانكين قطر آلوئول ها نسبت به گروه كنترل مى

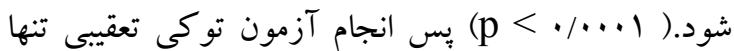

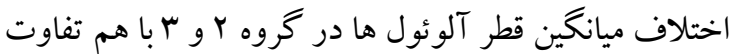

ميانكين قطر آلوئول ها. نتايج بررسى ميانگين قطر آلوئول ها در گروه هاى مورد بررسى نشان داد كه عصاره يتروسيلينوم كريسبوم در تمامى دوزها موجب افزايش معنى 


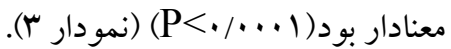

آمارى معنادار نداشت ولى در ساير حالات تفاوت آمارى

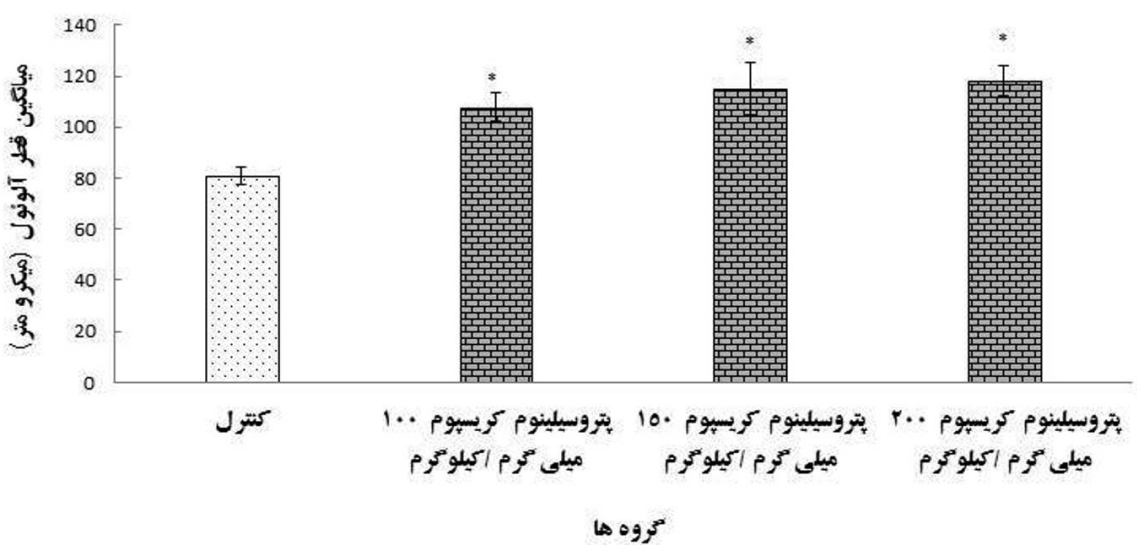

نمودار باثرات قتروسيلينوم كريسوم بر روى ميانكين قطر آلوئول ها در موشهاى صحرايى. *ق افزايش معنى در در تمامى گروه هاى يتروسيلينوم كريسيوم

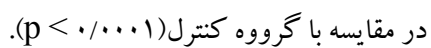

تعقيبى تنها اختلاف ميانگين تعداد آلوئول ها در گروه Y و

تعداد آلوئول ها. عصاره بتروسيلينوم كريسبوم در تمامى

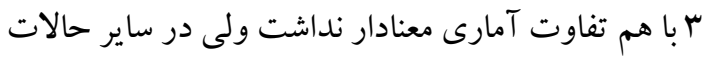
دوزهاى مورد مطالعه موجب افزايش معنى دارى در ميانكين

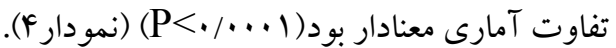

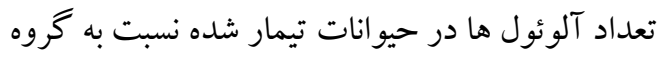

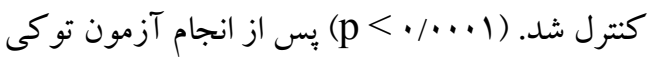

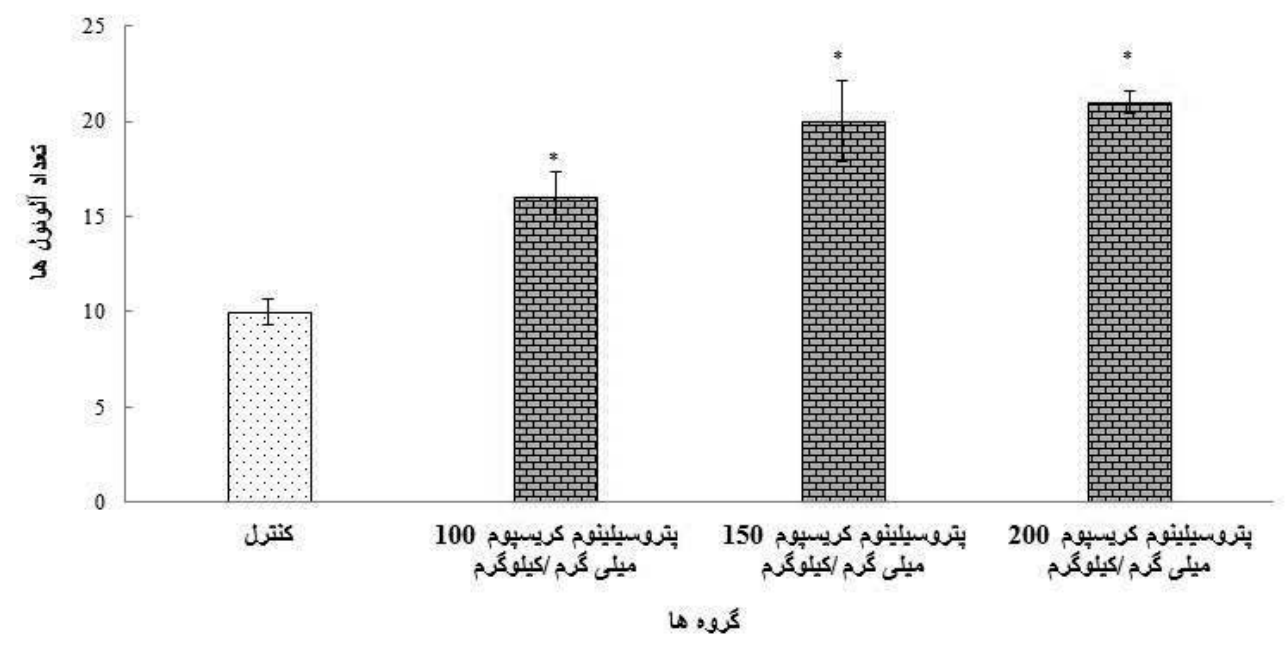

نمودار ץ- اثرات يتروسيلينوم كريسيوم بر روى ميانكين تعداد آلوئول ها در حيوانات مورد مطالعه. : افزايش معنى در در تمامى گروه هاى يتروسيلينوم

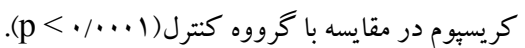


تيمار شده با عصاره يتروسيلينوم كريسيوم افزايش در اندازه بروسى بافت شناسى

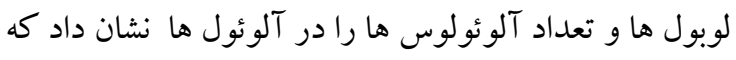
مقاطع رنغك آميزى شده توسط هماتو كسيلين/ ائوزين در ستى

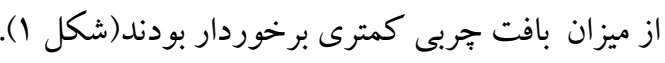

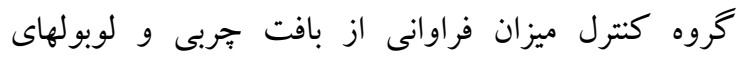

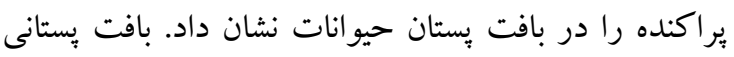

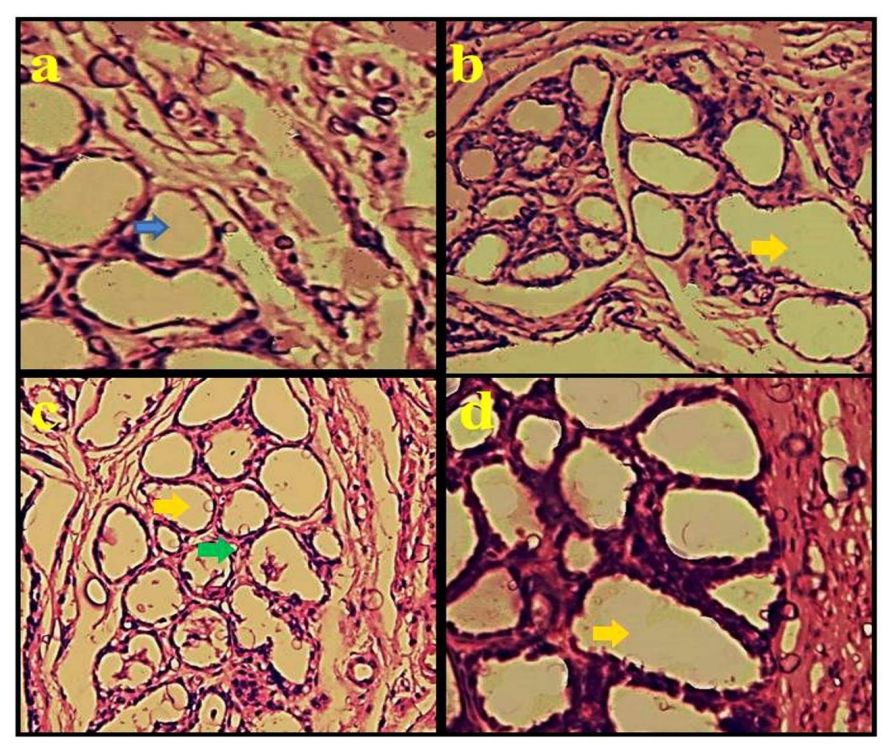

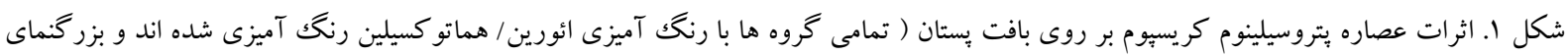

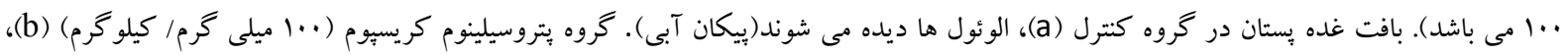

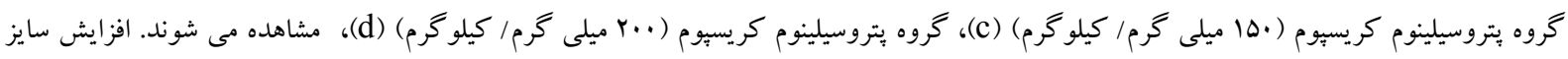

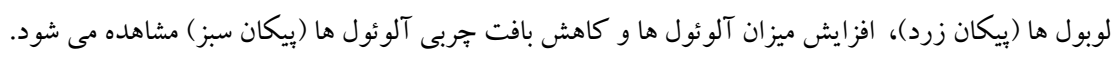

مى تواند اثرات متفاوتى بر اعضاء مختلف بدن داشته بحث

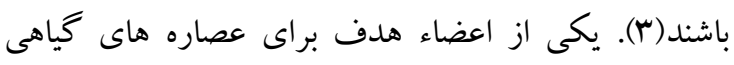
در مطالعه حاضر، اثرات عصاره بتروسيلينوم كريسيوم در غدد درون ريز و برون ريز بدن از جمله بخشهاى مختلف يارامترهاى توليد شير در بافت بستان مورد بررسى قرار

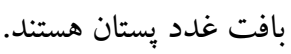

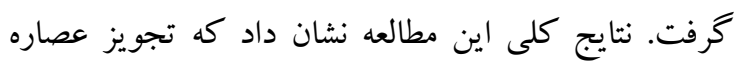

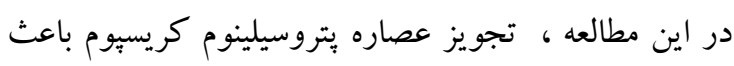

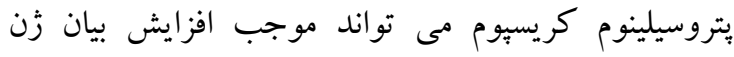

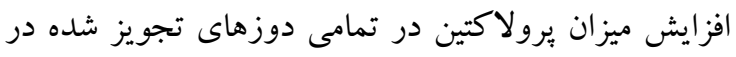

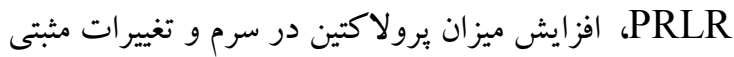

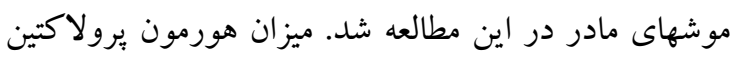
به طور فيزيولوزيكك در دوران باردارى و بس إز از زايمان

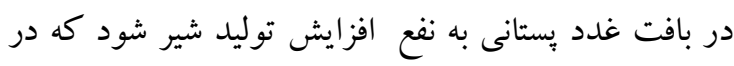

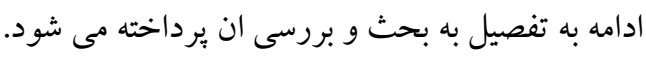
افزايش مى يابد و از جمله نقشهاى آن بايدارى فعاليت

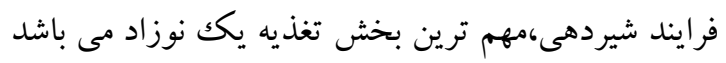

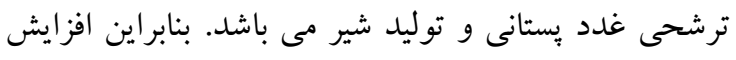

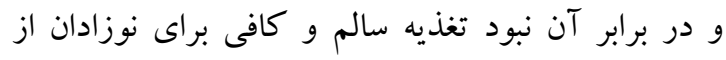

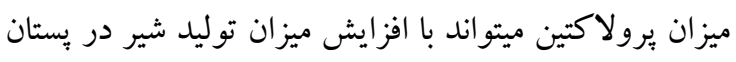

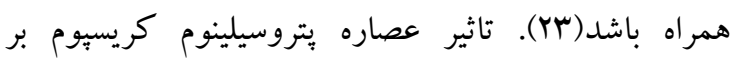

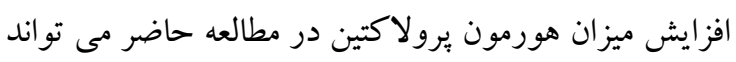

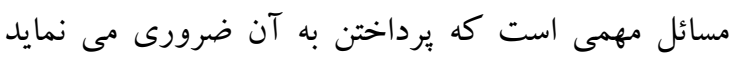

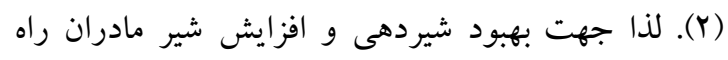
هاى درمانى جديدى مورد نياز است. عصاره هاى گياهان 
نشان دهنده آن است كه عصاره يتروسيلينوم كريسيوم توانسته است بر بافت يستان از لحاظ افزايش فاكتور هاى بافت شناسى توليد شير (آلوئول ها) اثرات مثبتى داشته باشد.

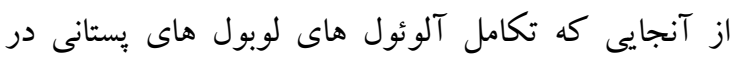
زمان شيردهى با ميزان يُرولاكتين سرم در ارتباط است(Y). به لهائ

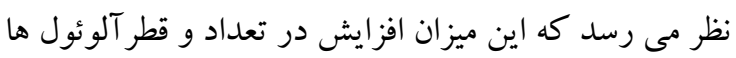
با افزايش در ميزان برولاكتين سرم نيز در ارتباط بوده است.

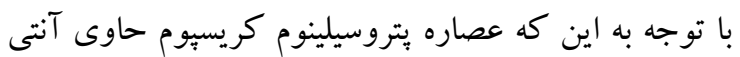
اكسيدانت هاى فراوان و ميزان تركيبات فلاونوئيدى مى باشد (r) و از آنجايى كه فلاونوئيدها جزء دسته ایى از

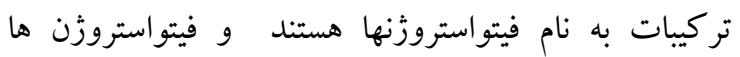

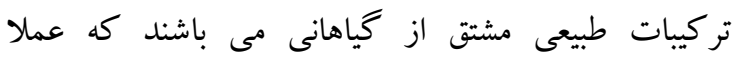

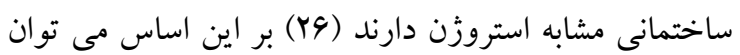

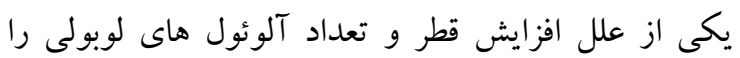
مرتبط با مكانيسم هاى استروزن دانست كه با افزايش ميزان

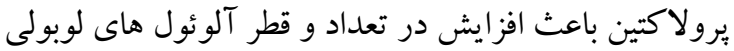
شده است. نتايج مطالعه جليلى و همكاران، نشان داد كه عصاره Utrica diocia به دلايل مختلف ازجمله وجود تر كيبات فلاونوئيدى و آنتى اكسيدانى موجب افزايش قطر و تعداد الوئولها در بافت يستان مى شود كه مويد نتايج مطالعه حاضر مى باشد (Y). در واقع در مطالعه حاضر نقش عصاره بر روى افزايش ميزان هورمون يُرولاكتين به علت خواص انتى اكسيدانى ، تانن، تر كيبات فلاونوئيدى و غيره كه بيشتر

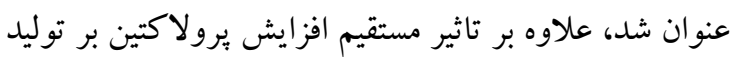
شير، آثار ثانويه بر بافت بستان را به صورت افزايش در برد تعداد و قطر الوئول ها نمايان مى سازد كه اين دو عامل نيز دليل ديخرى بر افزايش ميزان توليد شير هستند.

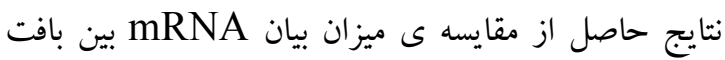

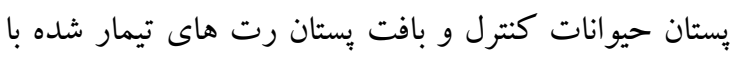
عصاره يتروسيلينوم كريسيوم نشان داد كه ميزان بيان زئن PRLR بتروسيلينوم كريسبوم به طور معنى دارى افزايش يافته است.
به علت وجود مواد غذايى و معدنى فراوان و ضرورى از قبيل ويتامين C، فيتواسترول، بروتئين (آمينواسيدهاى ضرورى) و مواد نشاسته اى باشد كه از طريق اين كياه به عنوان يكك سبزى به موشهاى ماده رسيده است (YF). همجنين با توجه به بررسى مطالعات مشايه كه بر روى

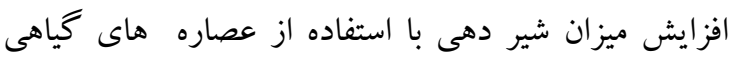
انجام شده است، به نظر مى رسد با توجه به اينكه اين كياه

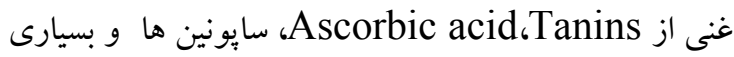

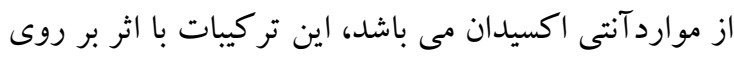

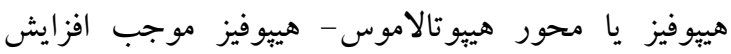

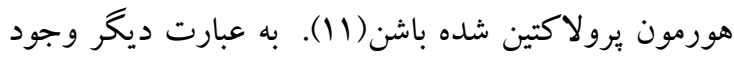
تانين از يكك طرف و همجينين وجود موارد آنتى اكسيدان

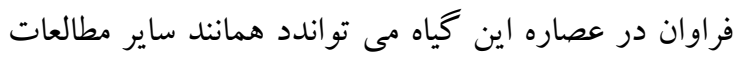

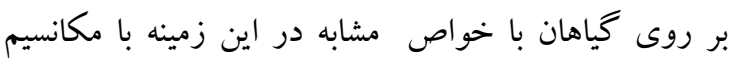
فوق موجب افزايش ميزان توليد شير در مطالعه حاضر شده باشد.نتايج مطالعه AL-Shemary و همكاران نشان داد كه تانين موجود در عصاره Ocimum gratissmum مى تواند موجب افزايش ميزان برولاكتين در خون شود كه نتايج حاصل از مطالعه حاضر را تاييد مى كند (1)). نتايج مطالعه Daniel و همكاران، نشان داد عصاره Cucurbita ميزان برولاكتين سرم را به طور معنى دارى بالا مع pepolinn ميبرد كه بر اثر يك گياه دارويى بر ميزان برولاكتين تاكيد

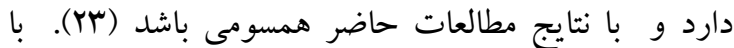

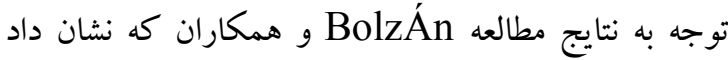
آنتى اكسيدان ها مى تواند موجب افزايش ميزان هورمون يرولاكتين در خون شوند (19) ، بنابراين به نظر مى رسد خو اص انتى اكسيدانى بالاى عصاره يتروسيلينوم كريسيوم در مطالعه حاضر مى تواند عامل ديخرى علاوه بر وجود تانين در افزايش ميزان هورمون يرولاكتين و متعاقبا افزايش ترك ميزان توليد شير در حيوانات مورد بررسى باشد (YF).

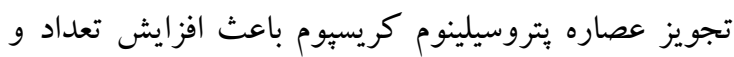
قطر آلوئول ها در گروه هاى مورد بررسى شد. اين مساله 


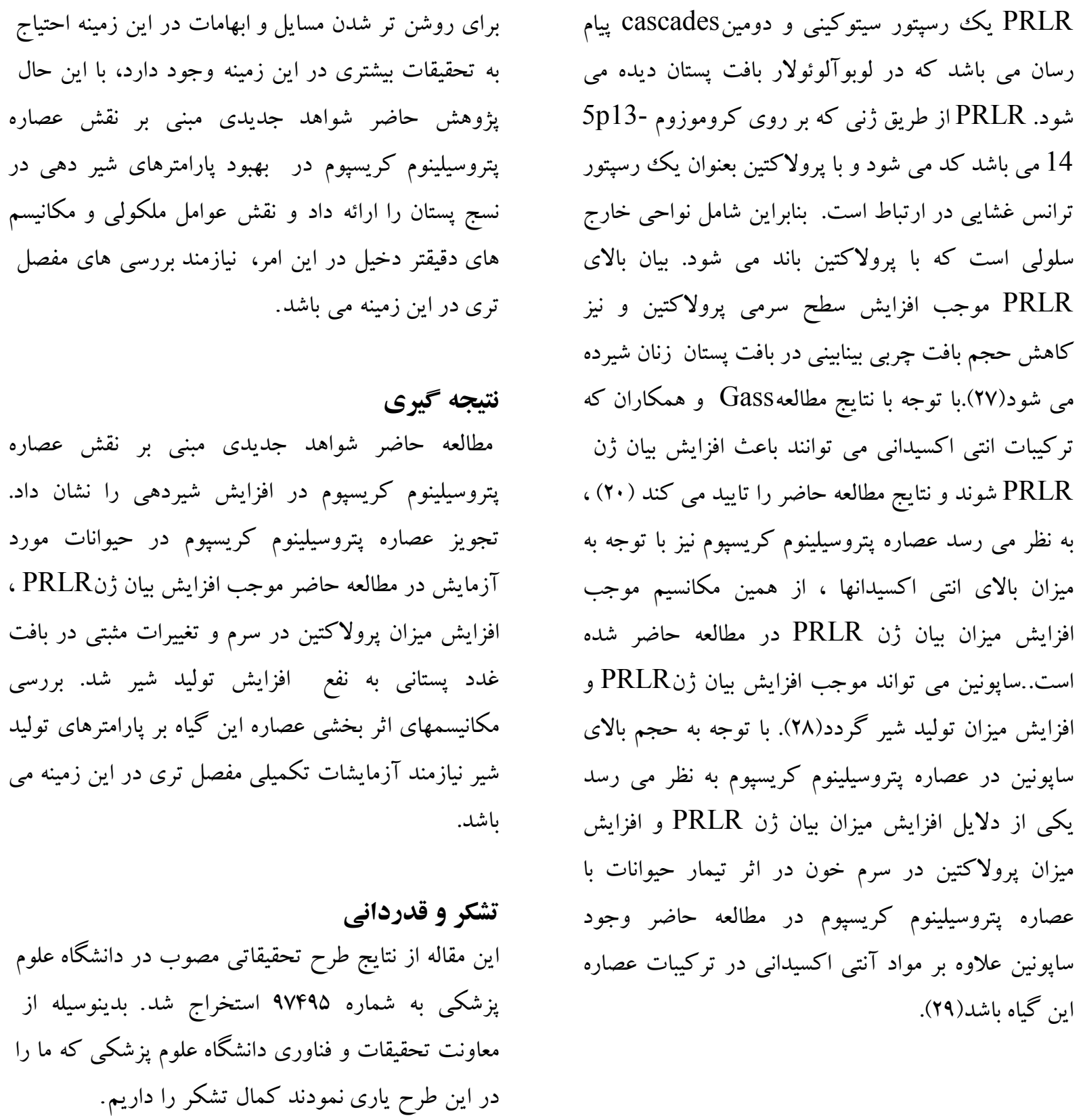

\section{Reference}

1. Zhou W, Yu Y, Qian Z. Challenges of breastfeeding in China under its universal two-child policy. J Matern Fetal Neonatal Med 2018:1-2.

2. Jalili C, Salahshoor M, Yousefi D, Khazaei M, Shabanizadeh Darehdori A, et al. Morphometric and hormonal study of the effect of utrica diocia extract on mammary glands in rats. Int J Morphol 2015;33:983-7.

3. Almqvist Tangen G, Bergman S, Dahlgren J, Roswall J, Alm B. Factors associated with discontinuation of breastfeeding before 1 month of age. Acta Paediatr 2012;101:55-60.

4. Taveras EM, Capra AM, Braveman PA, Jensvold NG, Escobar GJ, Lieu TA. Clinician support and psychosocial risk factors associated with breastfeeding discontinuation. Pediatrics 2003;112:108-15. 
5. Velle-Forbord V, Underdal MO, Vanky E. Breastfeeding and future maternal health-no causal evidence. JAMA Intern Med 2018;178:870-1.

6. Akinloye A, Oke B. Sex hormonal pattern of the female african giant rat (Cricetomys gambianus, Waterhouse) at different stages of the oestrous cycle. Nigerian Vet J 2012;33: 586-91.

7. Knoppert DC, Page A, Warren J, Seabrook JA, Carr M, Angelini M, et al. The effect of two different domperidone doses on maternal milk production. J Hum Lact 2013;29:38-44.

8. American Academy of Pediatrics Committee on Drugs. Transfer of drugs and other chemicals into human milk. Pediatrics 2001;108: 776-89..

9. Wong PY, Kitts DD. Studies on the dual antioxidant and antibacterial properties of parsley (Petroselinum crispum) and cilantro (Coriandrum sativum) extracts. Food Chem 2006;97:50515.

10. Petrolini FVB, Lucarini R, Souza MGMd, Pires RH, Cunha WR, Martins CHG. Evaluation of the antibacterial potential of Petroselinum crispum and Rosmarinus officinalis against bacteria that cause urinary tract infections. Braz J Microbiol 2013;44:829-34.

11. Corrêa Filho LC, Martinazzo AP, de Souza Teodoro CE, Vivès L. Microbiological quality and essential oil of parsley (Petroselinum crispum) submitted to the hygienizing and drying process. Ind Crops Prod 2018;114:180-4.

12. Ghorbani R, Mokhtari T, Khazaei M, Salahshoor MR, Jalili C, Bakhtiari M. The effect of walnut on the weight, blood glucose and sex hormones of diabetic male rats. Int $\mathrm{J}$ Morphol 2014;32:833-8.

13. Jalili C, Khani F, Salahshoor MR, Roshankhah SH. Protective effect of curcumin against nicotine-induced damage on reproductive parameters in male mice. Int $\mathrm{J}$ Morphol 2014;32:844-9.

14. Nielsen S, Young JF, Daneshvar B, Lauridsen S, Knuthsen P, Sandström B, et al. Effect of parsley (Petroselinum crispum) intake on urinary apigenin excretion, blood antioxidant enzymes and biomarkers for oxidative stress in human subjects. Br J Nutr 1999;81:447-55.

15. Jalili C, Salahshoor MR, Naderi T. The effect of hydroalcoholic extract of P. crispum on sperm parameters, testis tissue and serum nitric oxide levels in mice. Adv Biomed Res 2015;4:40.

16. Al-Howiriny T, Al-Sohaibani M, El-Tahir K, Rafatullah S. Preliminary evaluation of the anti-inflammatory and anti-hepatotoxic activities of parsley'petroselinum crispum in rats. J Nat Med 2003;3:54-62.

17. Heidari T, Moazedi AA, Seyyednejad SM, Borojeni MP. The role of histaminergic H2 receptors on spasmolytic activity of hydroalcoholic extract of parsley (Petroselinum crispum) Seeds in Isolated Rat's Ileum. J Nat Med 2018;17:114-24.

18. AL-Shemary NNA, Mousa SA, Muslim ZZ. Histological and hormonal study about the effect of aqueous extract of Ocimum gratissmum on female reproductive system in albino mice. J Pharm Sci Res 2018;10:765-7.

19. BolzÁn AD, Bianchi MS, Cónsole GM, Goya RG .Relationship between pituitary hormones, antioxidant enzymes, and histopathological changes in the mammary gland of senescent rats. Exp Gerontol 1997;32:297-304.

20. Gass S, Harris J, Ormandy C, Brisken C. Using gene expression arrays to elucidate transcriptional profiles underlying prolactin function. J Mammary Gland Biol Neoplasia 2003;8:269-85. 
21. Dastjerdi MN, Salahshoor M, Mardani M, Rabbani M, Hashemibeni B, Gharagozloo M, et al. The apoptotic effects of sirtuin1 inhibitor on the MCF-7 and MRC-5 cell lines. Res Pharm Sci 2013;8:79-89.

22. Nagano M, Kelly PA. Tissue distribution and regulation of rat prolactin receptor gene expression. Quantitative analysis by polymerase chain reaction. $\mathrm{J}$ Biol Chem 1994;269:13337-45.

23. Daniel E, Hamman W, Olorunshola K, Malgwi I. The study of effect of aqueous Cucurbita pepo linn seed extract on serum prolactine level of lactating female albinorats. Sci J Med Sci 2013;2:6-11.

24. Damabi NM, Moazedi A, Seyyednejad S. The role of $\alpha$-and $\beta$-adrenergic receptors in the spasmolytic effects on rat ileum of Petroselinum crispum Latifolum (parsley). Asian Pac J Trop Dis 2010;3:866-70.

25. Rezazad M, Farokhi F. Protective effect of Petroselinum crispum extract in abortion using prostadin-induced renal dysfunction in female rats. Avicenna J Phytomed 2014;4:312-9.

26. Haidari F, Keshavarz SA, Shahi MM, Mahboob SA, Rashidi MR. Effects of parsley (Petroselinum crispum) and its flavonol constituents, kaempferol and quercetin, on serum uric acid levels, biomarkers of oxidative stress and liver xanthine oxidoreductase aactivity inoxonate-induced hyperuricemic rats. Iran J Pharm Res 2011;10:811-9.

27. Jalili C, Salahshoor MR, Hoseini M, Roshankhah S, Sohrabi M, Shabanizadeh A. Protective effect of thymoquinone against morphine injuries to kidneys of mice. Iran J Kidney Dis 2017;11:142-50.

28. Benchaar C, McAllister T, Chouinard P. Digestion, ruminal fermentation, ciliate protozoal populations, and milk production from dairy cows fed cinnamaldehyde, quebracho condensed tannin, or Yucca schidigera saponin extracts. J Dairy Sci 2008;91:4765-77.

29. Simon JE, Quinn J. Characterization of essential oil of parsley. J Agric Food Chem 1988;36:467-72. 